\title{
Generativity, Sustainable Development and Green Consumer Behaviour
}

\section{Abstract}

Conserving the planet for the next generation has come to be an essential component of sustainable development, with "future generations" being the term most frequently included when citing definitions of sustainable development. However, beyond words, does a concern for a future beyond the current generation have any bearing on actions taken in the present? This paper examines the concept of generativity (concern for the future) as a component of sustainable development and specifically, in relation to green consumption. A sub-set of data gathered through a survey which sought to explore constructs for a model for green consumer behaviour has been used to reflect particularly, on the relationship between generativity and green behaviour. Further, the data has been deployed to explore comparisons on the basis of gender and age but also differences between respondents in the UK and Portugal. The results show a positive correlation between generativity and green consumption values, as well as between generativity and buying behaviour, and generativity and prosocial attitude. The data does not support gender difference in terms of levels of concern, or differences between the two countries but age, is shown to be an influencing factor. The paper concludes that the concept of generativity merits further exploration.

Key words: Generativity, Green consumption, Future Generations, Sustainable Development, Green Behaviour, Prosocial Attitudes

\section{Introduction}

The need for sustainable development has grown in significance at the global level since the eighties, when the World Commission on Sustainable Development (WCED) established the Brundtland Commission in 1983, to unite countries in the pursuit of addressing 
unsustainable development (WCED, 1987). Since then, with heightened awareness of global warming, continued environmental degradation and increased concerns about safeguarding the planet, many countries have developed and are refining strategies to address climate change; most are supporting actions to achieve the Sustainable Development Goals which now provide the overarching strategic umbrella for securing actions to address a sustainable future. In this context, research that seeks to understand the factors that influence more sustainable ways of living and those behaviours that are more likely to contribute to a better future, has come to prominence in the last decade. A particular focus has been given to trying to understand the factors that influence consumers to make green decisions and engage with greener purchasing behaviour (Joshi and Rahman, 2015; Tripathi and Singh, 2016) with some progress made in unpicking the relationships between having a general concern for sustainability and environmentally friendly actions and purchases. However, despite considerable research, studies reveal often contradictory results and a gap between intentions and actions; it is unclear why concerns for the environment are not always translated into environmentally friendly actions/activities and green consumer behaviours (Biswas 2017; He et al., 2016).

Thus, developing further understanding continues to be critically important in a context where over-consumption is leading to depletion of natural resources (Chen and Chai, 2010) and consumer household purchases have considerable responsibility for environmental damage (Grunert and Juhl, 1995) with detrimental impacts on future generations. An important component of securing a sustainable future will be to reduce production and consumption of products that damage the environment while promoting environmentally friendly goods and services (Liobikiene and Bernatoniene, 2017) but why do some consumers appear to care about the future of the environment more than others? Creating a greener future is tacit in much of the research, however the extent to which concern for the future moderates consumer decisions, is not directly considered; future generations, while important to definitions of sustainable development, are rarely mentioned in green consumer 
behaviour research. There is a paucity of research that considers the inter-generational aspect of sustainability (Urien and Kilbourne, 2011). Further, it is suggested that despite substantial research on a multiplicity of factors that influence green purchasing, the literature remains inconclusive; further factors and concepts merit consideration (Liobikiene and Bernatoniene, 2017; Joshi and Rahman, 2015). Nath et al. (2013) for example, suggest that the study of the enablers is crucial when it comes to understanding why consumers adopt green products or sustainable lifestyles, emphasising the role of environmental awareness, levels of education or literacy, environmental attitudes, labelling, financial incentives and green advertisements.

This paper aims to make a contribution by focusing on the extent to which the concepts of generativity and prosocial attitudes serve as influencing factors. The paper starts by considering the concept of future generations in regard to sustainable development, arguing that commitment to future generations is a potential driver for green consumption and thus might feature in marketing campaigns before going on to explore the concepts of generativity and prosocial attitudes, as constructs used to measure concern for the future and concern for others.

\section{Literature}

\subsection{Future Generations and Sustainable Development}

Formal concerns to protect current generations while also considering the welfare of future generations precede concerns with sustainable development. Unsurprisingly, in the devastating aftermath of the Second World War, the United Nations Charter sought to ensure a better future and declared that the peoples of the UN were "determined to save succeeding generations from the scourge of war..." (United Nations, 1945). Actions were needed in the present, to ensure that the past was not repeated in the future. 
In relation to the natural environment, the rights of future generations and ensuring fairness so that one generation would not take from the planet more than it put back emerged as a global policy concern in the seventies. Although the environment movement had been highlighting concerns about the relationship between economic growth and environmental degradation much earlier (Carson, 1962, for example), Limits to Growth (Meadows et al., 1977) drew global attention to the limits of the Earth's capacity to support continued economic expansion. The 1972 Stockholm Conference on the Human Environment highlighted the need "to protect and improve the environment for present and future generations" (United Nations, 1972, p4) and proposed that natural resources, including air, water, land, flora and fauna had to be safeguarded for present and future generations. While this triggered the development of International Law, treaties and instruments (for example, the 1973 Convention on International Trade and Endangered Species) and eventually led to the development of the precautionary principle, it was not until the later publication of Our Common Future (WECD, 1987) that concern for generations to come, became a more public issue and a more widely understood consideration.

The Brundtland Commission in 1987 (WECD, 1987) established the most frequently cited definition of SD and stressed that it was not just about present needs:

"Sustainable development is development that meets the needs of the present without compromising the ability of future generations to meet their own needs."

Albeit that the definition has been criticised and contested (Leal Filho, 2010), it continues to be used today and has become commonly known (if not fully understood). The definition firmly established the principle of inter-generational equity.

Intergenerational equity is based on the concept of fairness and rights. It suggests that as each generation inherits the Earth from those who have gone before the present generation has a moral responsibility to ensure that the legacy to future generations is in a fair and sustainable condition. Weiss (1992), in a useful summary of how the legal framework has 
developed, suggests that sustainable development means recognising that we "hold the natural and cultural environment of the Earth in common with other members of the present generation and with other generations, past and future" (Weiss 1992, p.8). This requires a commitment to equity with future generations - those who are not yet born, would want to inherit a planet that is at least as good, as the environment enjoyed by previous generations. Ensuring equitable access to natural resources is a central concern and it behoves one generation not to exhaust finite resources, without putting something back.

Our Common Future not only set the definition but also firmly set the principle of sustainable development to meet human development goals. It also established that development had to take place within a delicate eco-system, and warned that unsustainable consumption and lifestyles would deplete finite resources in a way that the future would be compromised. Solutions would require collective responsibility; awareness raising and education to inculcate behaviour change, would be necessary at all levels, across the globe.

But how much has changed since then? What steps are being taken to conserve the planet so that it sustains life in the future? It is beyond the scope of this paper to detail the history of the various global summits and declarations that followed the Stockholm Conference. Suffice to say, the concerns have been repeated and writ large but progress has been slow. Actions and solutions now fall under the umbrella of the Sustainable Development Goals (United Nations, 2015) which represent "a call for action to change our world". The SDGs (Sustainable Development Goals) acknowledge strongly that the planet is at risk: environmental degradation, bio-diversity loss, pollution and climate change are a threat to survival. Questions remain as to whether the SDGs will be achieved, whether governments will sufficiently follow through on actions and whether concern for the environment and concern for the future, will influence changes in individuals' consumption patterns to the extent that a healthy planet is the legacy to future generations. It is however clear, that since Brundlandt, and with global attention now focused on the SDGs, and the imminent threat of 
global warming levels being exceeded, that the public is more aware that the future is in jeopardy and changes in behaviour are necessary.

\subsection{Generativity, Green Behaviour and Prosocial Attitudes}

The concept of generativity was initially proposed by Erikson (1950) as one of the eight stages of human life (generativity versus stagnation), which occurs at some point after the age of 35 years. The concept involves having a concern for establishing and guiding the next generation. Thus, Kotre (1984) defined the concept of generativity as the desire to live in a way that whatever is done, will have an impact which lasts beyond the individual's lifespan; a "desire to invest one's substance in forms of life and work that will outlive the self" ( $p 10)$. Kotre suggested that generativity is not associated with a particular phase of life but more an impulse that might be released throughout.

To McAdams and St. Aubin (1992), generativity is composed of seven dimensions, namely, inner desire, cultural demand, conscious concern, belief, commitment, action, and generative narrative. The individual's inner desire and society's demand for generative behaviours are the motivational factors that lead to conscious concern. In turn, a belief in the human race together with conscious concern will lead to commitments, which will be reflected in future plans and goals, and that eventually, will result in action accompanied by an individual generative narrative.

According to Frensch et al. (2007) and McAdams and Logan (2004), generative behaviour may be observed in family life, professional activities, behaviours of volunteering, participation in political and religious organisations, in activism and even in leisure activities. However, it is important to distinguish between generativity behaviour and generativity concern, since although related they reflect different dimensions of generativity. The concept has already been applied in the context of eco-consumption behaviour and intentions, and 
Urien and Kilbourne (2011) describe it as "a resource encouraging people towards the public good, maintaining continuity from one generation to the next" (p.73).

In order to link generativity with environmental consumption, it is necessary to introduce here the topics of green consumption values and green buying behaviour, concepts themselves inter-related (Paço et al., 2019). According to Haws et al. (2014, p. 337) green consumption values can be defined as "the tendency to explore the value of environmental protection through one's purchases and consumption behaviours". As such, it is supposed that individuals with stronger green consumption values are more concerned with preserving natural resources and as a consequence will be more likely to buy in a responsible way making environmentally friendly choices that reflect their concerning about the future of the planet. Additionally, environmental awareness can be considered as an enabler for green buying behaviour. Environmentally aware individuals tend to be more proactive when it comes to protecting the environment (Nath et al., 2013).

Urien and Kilbourne (2011) report that those people who score high on generativity are more likely to support environmentally responsible consumption behaviours, i.e., individuals who believe their contributions to the future are relevant, manifested greater intention to engage in activities such as buying organic, saving energy, reducing household waste and buying green products, particularly when self-enhancement, also tested in their study, is high. As environmental concern and sustainability have a long-term orientation perspective crossing generations, Urien and Kilbourne suggest that generative concern is predicted to be a relevant motivating indicator for environmental action.

Thus, the following hypotheses can be established:

H1: Concern for the future (GEN) is positively correlated with individuals' Green Consumption Values (GREEN).

H2: Concern for the future (GEN) is positively correlated with individuals' Buying Behaviour (BB). 
In fact, an overall positive association between generativity and environmental behaviour is generally reported. Wells et al. (2016) undertook one of the first studies to apply the construct to the hospitality industry and to behaviour in the workplace. Although their study was not fully conclusive and had a number of limitations, they suggest a potential association between the constructs.

Previously, Chan (2009) explored the link between generativity and environmental concern/sustainability and concluded that generativity plays an important role in environmental commitment. More recently, Alisat (2015) and Matsuba et al. (2012) proved a relationship between generativity and environmental activism and environmental involvement/attitudes respectively. Wells et al. (2016) also emphasised the link between generativity and environmental attitudes and behaviour.

However, it is important to note that individual behaviour does not occur in a vacuum, of major relevance are the social aspects that influence behaviour and the relationship between the social and green behaviour, as well as to understand whether concern for the future also conditions more prosocial attitudes. As noted by Welte and Anastasio (2010), the social context and a belief about how other people perceive certain behaviour, can be a relevant indicator of green behaviour. Weinstein and Ryan (2010) suggest that pro-social behaviour is about cooperation with others and actions to protect or enhance the well-being of others. Such actions might include environmental conservation activities. Steele et al. (2008) suggest that those with a prosocial personality are more likely to behave in ways that are altruistically motivated. Nath et al. (2013) highlight the inter-relationships between peer groups and cultural values as enablers of pro environmental attitudes but suggest that the relationship needs to be verified empirically in the context of green behaviours. However, Osgood and Muravens (2015) note inconsistency between prosocial affect and corresponding behaviours, advocating that efforts to intensify prosocial behaviours should focus on encouraging prosocial attitudes as well as diminishing the perceived cost or trouble to the individual. 
Regarding prosocial attitudes, the following hypothesis is established:

H3: Concern for the future (GEN) is positively correlated with individuals' Prosocial Attitude (PSA).

Nevertheless, despite some positive research results, Urien and Kilbourne (2011, p. 82) confirm that "little empirical research has been carried out regarding intergenerational aspects of the environmental problem, which are intimately bound up with sustainability". As conserving the planet for 'future generations' is an important aspect of most definitions of sustainability and central to 'Our Common Future' (WECD, 1987) this seems to be an important concept to understand further.

There is however some disagreement intrinsic to the concept of generativity, in particular the notion of linking the concept to a particular phase of an individual's life, as initially stated by Erikson (1950). McAdams and Logan (2004) have associated the concept with any stage of adulthood however; empirical research has provided contradictory results. For instance, Warburton and Gooch (2007) found that environmental generativity tended to be more evident in the elderly, while Ryff and Heincke (1983) found counter evidence for young people. In addition, the research by McAdams and Aubin (1992) explored the relationship between generativity and the existence of children with significant results, suggesting that the presence of children is a further factor for consideration.

Although there are studies that explore gender difference in relation to green behaviour (for example, Han et al., 2009; Lee 2009; Malik 2017) results are contradictory. There are no studies which show that gender is significant in relation to generativity.

Thus, based on the importance of concern for the future, and the gaps in the research on the concept of generativity in the context of a need for green consumption, some additional hypotheses were stated to explore demographic and geographic variables: 
H4: There are differences between males and females regarding concern for the future (GEN)

H5: There are differences between ages regarding concern for the future (GEN)

H6: There are differences between people with children and people without children regarding concern for the future (GEN)

H7: There are differences between individuals from Portugal (PT) and the United Kingdom (UK) regarding concern for the future (GEN)

\section{Method}

This paper has used data originally gathered but not fully utilised, as part of an earlier piece of research (Paço et al., 2019). The earlier study did not include analysis of the concept of generativity in relation to other variables. The sections that follow describe method and have been annotated from the earlier study, making transparent the original approach to data collection.

\subsection{Questionnaire Design and Variable Measurement}

A survey was developed with the aim of gathering data online, as an expedient method. The survey took the structure of a self-administered questionnaire designed to test particular variables (see Appendix A). The survey comprised mainly closed questions, organised around sections, to include: (i) opinion questions (prosocial attitudes, green values and generativity); (ii) frequency questions (buying behaviour); and (iii) demographics (age, gender, level of education, nationality, parental status).

The statements were selected from already tested scales and respondents were asked to reply using a seven point scale, where 7 equals totally agree, or always; 1 equals either totally disagree, or never, depending on the question. 
The first draft of the questionnaire was piloted using a sample of 24 individuals to identify and correct issues of language and sense.

Generativity (GEN) is related to a concern for establishing and guiding the next generation. A set of 16 questions adapted from the McAdams and St. Aubin (1992) study, were used to examine individuals' level of "environmental altruism". The concept has already been applied to eco-consumption behaviour and intentions by Urien and Kilbourne (2011). Previously, Chan (2009) had also explored the link between generativity and environmental concern/sustainability.

In order to consider green consumption, the GREEN scale used by Haws et al. (2014) was used as a predictor of consumer preference for environmentally friendly products. The sixitem scale GREEN was also used recently by Bailey et al. (2016 a, b).

To measure Buying Behaviour (BB), a scale that has been tested and used in consumer behaviour models previously (Paço et al. 2013a, 2014) was selected. The scale is based on ten items selected from the Straughan and Roberts (1999) 'Ecologically Conscious Consumer Behaviour' (ECCB) scale. The items relate to such things as packaging, energyefficiency, polluting or recycled products.

Prosocial Attitudes (PSA) were tested using a scale adapted from Osgood and Muraven (2015). This scale was chosen because of its capacity to measure altruistic behaviours usually related to environmental concern. Previously, Zabkar and Hosta (2013) deployed this scale and argued that prosocial perceptions could address the difference between intention and green consumption.

\subsection{Research sample and Data Collection}

The data was gathered using convenience sampling from the authors' countries of residence, England and Portugal with the intention of expanding the sample to include other countries at a later stage. Portugal, contrasts with England in socio-economic terms but was 
deemed a good comparator in this study because it represents a country that has been slower to engage with environmental issues and sustainable development than England. Such differences between the two countries are evidenced by the European Commission's (2014), Special Eurobarometer 416 which shows that while both English (94\%) and Portuguese $(97 \%)$ respondents believe that protecting the environment is important, and agree that environmental issues have a direct effect on their daily life, there are significant differences in relation to behaviours across a number of measures, for example, waste, purchase of environmentally friendly products, car use etc. In regard to greener purchasing, Portugal was placed at the end of the rankings, whereas English citizens ranked above the mean.

The questionnaire was first developed in English before translation into Portuguese, using standard back-translation protocol. A few adjustments were made to enhance sense-making. The questionnaire was distributed electronically using Survey Monkey. Data was collected over a two-month period. In order to maximise response rate, respondents were asked to cascade the questionnaire further, thus increasing the final number completed. The aim of attaining a 400-500 response rate was achieved, with 471 questionnaires were collected (240 from PT and 231 from UK) albeit that the two samples are not fully matched.

After collection, the data was statistically analysed and interpreted using the statistical software IBM SPSS version 25. IBM SPSS Statistics is one of world's leading statistical software packages used to solve business and research problems in social sciences by means of ad-hoc analysis, hypothesis testing, and predictive analytics. The software was selected because it reads the databases generated by online survey platforms, such the one used in this survey. Several previous studies in this field have used this software, such as Mostafa (2007), Whitmarsh and O'Neill (2010), Paço and Reis (2012) and Carfora, Caso, Sparks and Conner (2017). 


\section{Results: presentation and discussion}

The sample composition is shown in Table 1. As can be seen, the UK sample comprised a greater number of older respondents than the UK sample; the sample overall is heavily skewed towards female respondents; the majority of respondents are educated at graduate level.

Table 1 - Sample composition

\begin{tabular}{c|c|c|c|c|c|c}
\hline Age & Portugal & $\%$ & UK & $\%$ & Total & $\%$ \\
\hline $15-25$ & 72 & $31 \%$ & 31 & $14 \%$ & 103 & $22 \%$ \\
$26-35$ & 34 & $14 \%$ & 27 & $12 \%$ & 61 & $13 \%$ \\
$36-45$ & 57 & $24 \%$ & 48 & $21 \%$ & 105 & $23 \%$ \\
$46-55$ & 38 & $16 \%$ & 66 & $29 \%$ & 104 & $22 \%$ \\
$56-65$ & 13 & $6 \%$ & 32 & $14 \%$ & 45 & $10 \%$ \\
$66-75$ & 6 & $3 \%$ & 19 & $8 \%$ & 25 & $5 \%$ \\
$76-85$ & 0 & $0 \%$ & 4 & $2 \%$ & 4 & $1 \%$ \\
Missing & 15 & $6 \%$ & 2 & $1 \%$ & 17 & $4 \%$ \\
Total & 235 & $100 \%$ & 229 & $100 \%$ & 464 & $100 \%$ \\
\hline Gender & Portugal & $\%$ & UK & $\%$ & Total & $\%$ \\
\hline Male & 85 & $36 \%$ & 61 & $27 \%$ & 146 & $31 \%$ \\
Female & 148 & $63 \%$ & 167 & $73 \%$ & 315 & $68 \%$ \\
Missing & 2 & $1 \%$ & 1 & $0 \%$ & 3 & $1 \%$ \\
Total & 235 & $100 \%$ & 229 & $100 \%$ & 464 & $100 \%$ \\
\hline School Level & Portugal & $\%$ & UK & $\%$ & Total & $\%$ \\
\hline Graduate & 139 & $59 \%$ & 183 & $80 \%$ & 322 & $69 \%$ \\
Secondary & 74 & $31 \%$ & 26 & $11 \%$ & 100 & $22 \%$ \\
Elementary & 19 & $8 \%$ & 19 & $8 \%$ & 38 & $8 \%$ \\
Missing & 3 & $1 \%$ & 1 & $0 \%$ & 4 & $1 \%$ \\
Total & 235 & $100 \%$ & 229 & $100 \%$ & 464 & $100 \%$ \\
\hline Parental status & Portugal & $\%$ & UK & $\%$ & Total & $\%$ \\
\hline With children & 114 & $49 \%$ & 135 & $59 \%$ & 249 & $54 \%$ \\
Without children & 119 & $51 \%$ & 93 & $41 \%$ & 212 & $46 \%$ \\
Missing & 2 & $1 \%$ & 1 & $0 \%$ & 3 & $1 \%$ \\
Total & 235 & $100 \%$ & 229 & $100 \%$ & 464 & $100 \%$ \\
\hline
\end{tabular}

Before testing the hypotheses, the sample was analysed regarding outliers. All notable outliers were removed. To test hypotheses 1, 2 and 3 a correlation analysis was carried out. The results are presented in table 2. 
Table 2 - Correlations between GEN, BB, GREEN and PSA

\begin{tabular}{ll|l|r|r|r} 
& & $\begin{array}{c}\text { Generativity } \\
(\text { GEN) }\end{array}$ & $\begin{array}{c}\text { Buying } \\
\text { Behaviour } \\
\text { (BB) }\end{array}$ & $\begin{array}{c}\text { Green } \\
\text { Consumpti } \\
\text { on Values } \\
\text { (GREEN) }\end{array}$ & $\begin{array}{c}\text { Prosocial } \\
\text { Attitude } \\
\text { (PSA) }\end{array}$ \\
\hline \multirow{2}{*}{ Generativity } & Pearson Correlation & 1 & $.211^{* *}$ & $.222^{* *}$ & $.164^{* *}$ \\
\cline { 2 - 7 } & Sig. (2-tailed) & & .000 & .000 & .000 \\
\cline { 2 - 7 } & $\mathrm{N}$ & 464 & 462 & 464 & 464 \\
\hline
\end{tabular}

**. Correlation is significant at the 0.01 level (2-tailed).

As can be observed in Table 2, the correlation between concern for the future (Generativity) and green consumption values (Green Values) is positive and significant at the 0.01 level (2tailed). This means that an increase of one unit in generativity will lead to an increase of $22.2 \%$ on green values. The results bring support to Hypothesis 1: Concern for the future (GEN) is positively correlated with individuals' Green Consumption Values (GREEN).

The results also support Hypothesis 2, which states that concern for the future (GEN) positively affects individuals' buying behaviour (BB): the correlation between Generativity and Buying behaviour is positive, significant and of 0.211 . This is in line with the research by Paço et al. (2019) where it is noted that individuals with stronger green consumption values are more concerned with environmental preservation and are more environmentally responsible, demonstrating concern for the future. In the same vein, Urien and Kilbourne (2011) state that those individuals evidencing high levels of generativity are more predisposed to have more environmentally responsible consumption behaviours. In fact, a positive association between generativity and environmental behaviour is usually reported by several authors (e.g. Wells et al. 2016) and further supported by this present study.

Hypothesis 3: Concern for the future (GEN) is positively correlated with individuals' Prosocial Attitude (PSA), is also supported by the results as shown in Table 2. The correlation between generativity and prosocial attitude turned out to be significant, positive and of 0.164 . 
Regarding this relationship, it was not possible to find evidence of other studies in the literature testing the association between these constructs. This can therefore be considered of novelty value, in this research.

Hypotheses 4, 5, 6 and 7 were tested through One-Way ANOVA and Welch and BrownForsythe robust tests of Equality of Means.

Since ANOVA has as presumptions the homogeneity of variances and normality of variables, normality for generativity was tested first. The Kolmogorov-Smirnov test achieved a statistic of 0.041 and a significance of 0.063 , revealing no problems with normality. The next step was to proceed with the homogeneity of variances test (Table 3). As observed in Table 3, there is homogeneity of variances between the Male and Female group, since significance is above 0.05 . With equal variances assumed, a one-Way ANOVA analysis was conducted (Table 4). The one-way ANOVA results show that there is not a significant difference between the generativity level between males and females ( $F=0.983 ; \mathrm{Sig}=0.375)$. Based on these results, Hypothesis 4 is not supported. Regarding the relationship between gender and generativity, it was not possible to find in the literature other researches testing this relationship.

Table 3 - Test of Homogeneity of Variances for gender

\begin{tabular}{ll|r|r|r|r} 
& & Levene Statistic & df1 & df2 & \multicolumn{1}{c}{ Sig. } \\
\hline Generativity & Based on Mean & .230 & 2 & 461 & .794 \\
\cline { 2 - 6 }$($ GEN) & Based on Median & .146 & 2 & 461 & .864 \\
\cline { 2 - 6 } & $\begin{array}{l}\text { Based on Median and with } \\
\text { adjusted df }\end{array}$ & .146 & 2 & 453.267 & .864 \\
\cline { 2 - 6 } & Based on trimmed mean & .224 & 2 & 461 & .799 \\
\hline
\end{tabular}

Table 4 - ANOVA results for gender

\begin{tabular}{lr|r|r|r|r} 
& Sum of Squares & Df & Mean Square & F & \multicolumn{1}{c}{ Sig. } \\
\hline Between Groups & .704 & 2 & .352 & .983 & .375 \\
\hline Within Groups & 165.134 & 461 & .358 & & \\
\hline
\end{tabular}


To test the differences between people with different ages, Hypothesis 5, the variable age was transformed into 3 intervals: $<25$ years old; [25-50] years old and $>51$ years old.

In table 5 are the results of the homogeneity of variances test. As observed, there is not homogeneity of variances between the different age groups, since significance is above 0.05 .

Table 5 - Test of Homogeneity of Variances for age

\begin{tabular}{lr|r|r|r} 
& Levene Statistic & df1 & df2 & \multicolumn{1}{c}{ Sig. } \\
\hline Generativity (GEN) & 4.233 & 2 & 461 & 0.015 \\
\hline
\end{tabular}

Since no equal variances are assumed, ANOVA cannot be carried out and we opted for the robust tests of Welch and Brown-Forsythe to test the difference between means. Table 6 presents these results. According to the results, there is a significant difference between the generativity level between ages, since significance values for Welch and Brown-Forsythe tests are both below 0.05. Based on these results, Hypothesis 5 is supported.

Table 6- Test of equality of means for age

\begin{tabular}{l|r|r|r|r} 
Generativity (GEN) & Statistics & gl1 & gl2 & \multicolumn{2}{l}{ Sig. } \\
\hline Welch & 3,401 & & 238,608 &, 035 \\
\hline Brown-Forsythe & 3,235 & & 355,618 &, 041 \\
\hline
\end{tabular}

As shown in figure 1, people with less than 25 years old are the ones that present the lowest mean for generativity.

Figure 1 - Difference of means between peoples with different ages 


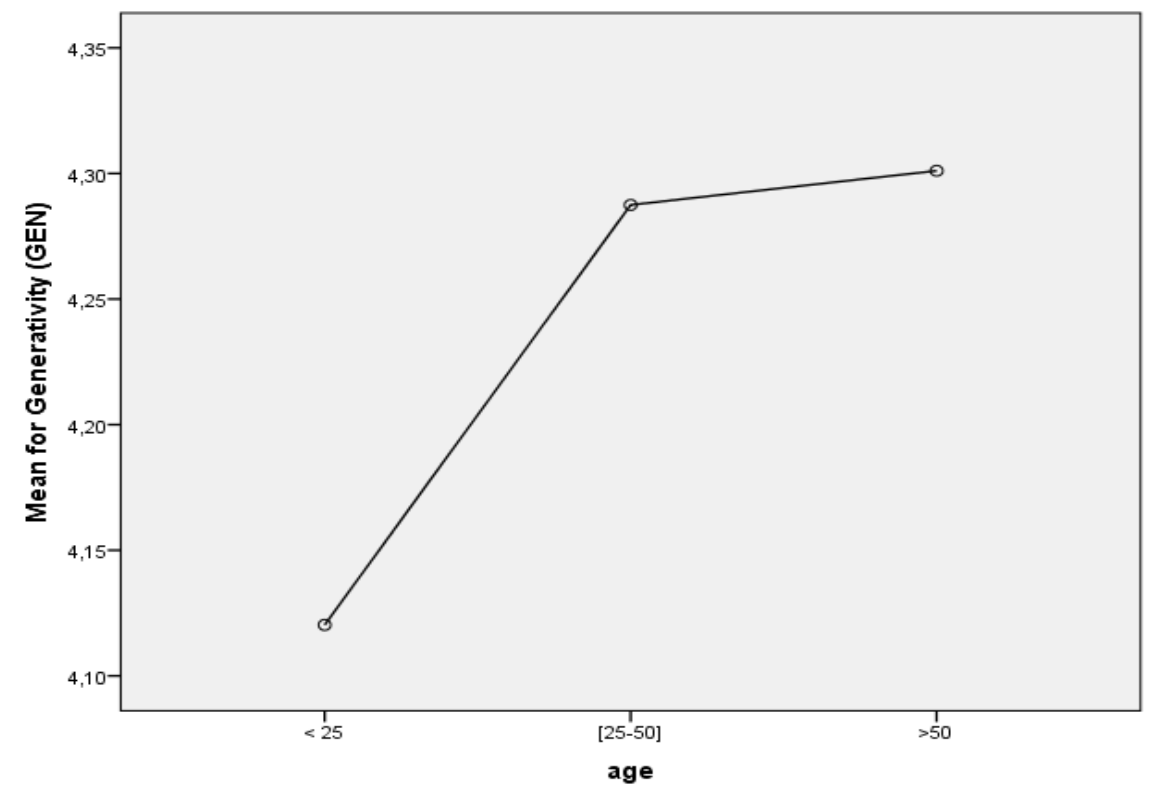

With regard to tests of hypothesis 6 , Table 7 shows the results of the Homogeneity of Variances test and Table 8 the ANOVA results.

Table 7 - Test of Homogeneity of Variances for groups with and without children

\begin{tabular}{|c|c|c|c|c|c|}
\hline & & Levene Statistic & df1 & df2 & Sig. \\
\hline \multirow{4}{*}{$\begin{array}{l}\text { Generativity } \\
\text { (GEN) }\end{array}$} & Based on Mean & 1.325 & 2 & 461 & .267 \\
\hline & Based on Median & 1.250 & 2 & 461 & .287 \\
\hline & $\begin{array}{l}\text { Based on Median and with } \\
\text { adjusted df }\end{array}$ & 1.250 & 2 & 449.206 & .287 \\
\hline & Based on trimmed mean & 1.340 & 2 & 461 & .263 \\
\hline
\end{tabular}

The homogeneity of variances test shows that there is homogeneity of variances. The oneway ANOVA results show that there is a significant difference between the mean of the group with children and the group without children ( $F=3.53$, Sig=0.03), thus providing support for Hypothesis 6. The difference between the means can be observed in Figure 1 , where we can observe that people with children show a higher level of generativity, that is, concern for the wellbeing of future generations. This is a similar outcome to the study 
performed by McAdams and Aubin (1992) who reported significant scores between generativity and the existence of children.

Table 8 - ANOVA for groups with and without children

\begin{tabular}{lr|r|r|r|r} 
& Sum of Squares & Df & Mean Square & F & \multicolumn{1}{c}{ Sig. } \\
\hline Between Groups & 2.500 & 2 & 1.250 & 3.528 & .030 \\
\hline Within Groups & 163.339 & 461 & .354 & & \\
\hline Total & 165.839 & 463 & & & \\
\hline
\end{tabular}

Figure 2 - Difference of means between the group with children and the group without children

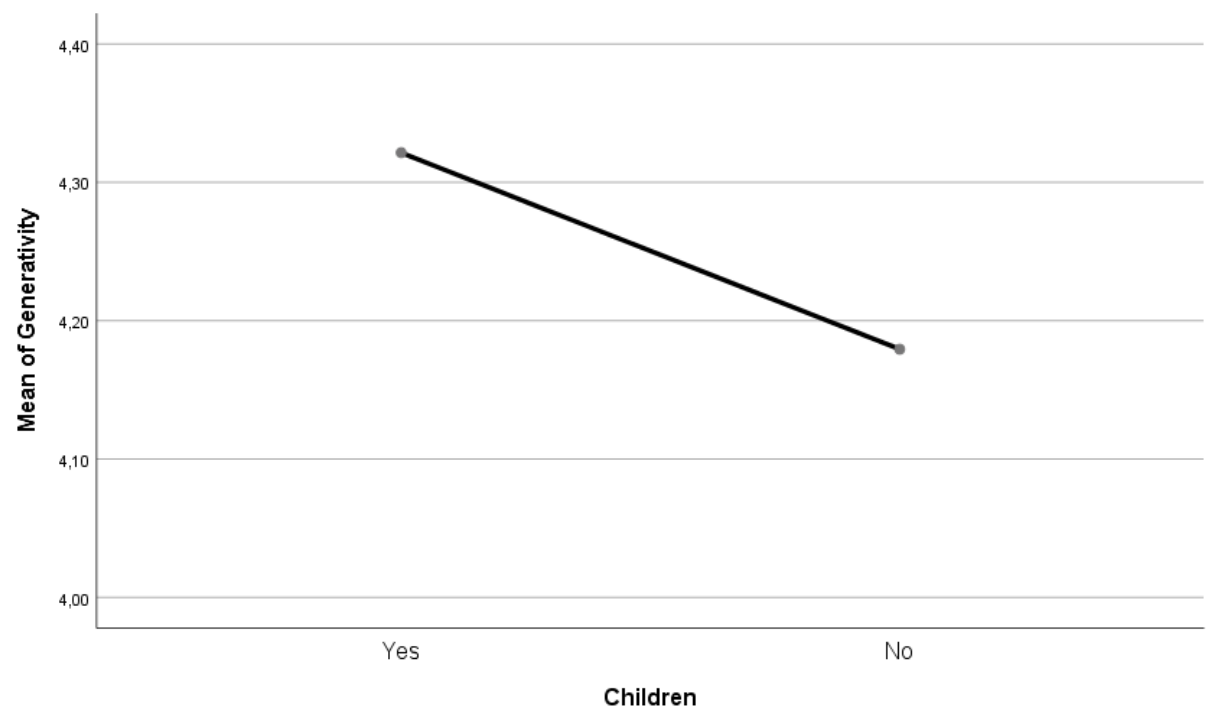

Table 9 presents the results for the test of homogeneity of variances for the Portuguese group and the UK group. The results show that the assumption of equality of variances was not violated as the significance is 0.4 , thus higher than the significance level of 0.05 . We then proceeded with the one-way ANOVA. The ANOVA test results are presented on table 10.

Table 9 - Test of Homogeneity of Variances for the Portuguese and UK group

\begin{tabular}{|c|c|c|c|c|c|}
\hline & & Levene Statistic & $\mathrm{df1}$ & df2 & Sig. \\
\hline \multirow{4}{*}{$\begin{array}{l}\text { Generativity } \\
\text { (GEN) }\end{array}$} & Based on Mean & .709 & 1 & 462 & .400 \\
\hline & Based on Median & .633 & 1 & 462 & .427 \\
\hline & $\begin{array}{l}\text { Based on Median and with } \\
\text { adjusted df }\end{array}$ & .633 & 1 & 445.496 & .427 \\
\hline & Based on trimmed mean & .704 & 1 & 462 & .402 \\
\hline
\end{tabular}


In regard to Table 10, there is not a significant difference between the mean level of generativity between the Portuguese and the English group $(F=0.661$, Sig. $=0.417)$, thus there is not support for Hypothesis 7. This supports the results of a previous study, Paço et al. (2013b) where university students from four countries were compared (Portugal, Spain, England and Germany) and no significant differences in the generative construct were found, although English students reported a lower mean $(M=4,871, S D=1,2787)$ when compared with the Portuguese $(M=4,967 ; S D=1,3676)$.

Table 10 - ANOVA results for the Portuguese and English group

\begin{tabular}{lr|r|r|r|r} 
& Sum of Squares & \multicolumn{1}{c}{ df } & Mean Square & F & \multicolumn{1}{c}{ Sig. } \\
\hline Between Groups & .237 & 1 & .237 & .661 & .417 \\
\hline Within Groups & 165.602 & 462 & .358 & & \\
\hline Total & 165.839 & 463 & & & \\
\hline
\end{tabular}

Table 11 presents an overview of the results of the hypotheses tested.

Table 11 - Hypotheses tested and results

\begin{tabular}{|l|c|}
\hline Hypotheses & Result \\
\hline $\begin{array}{l}\text { H1: Concern for the future (GEN) is positively correlated with } \\
\text { individuals' Green Consumption Values (GREEN). }\end{array}$ & Supported \\
\hline $\begin{array}{l}\text { H2: Concern for the future (GEN) is positively correlated with } \\
\text { individuals' Buying Behaviour (BB). }\end{array}$ & \\
\hline $\begin{array}{l}\text { H3: Concern for the future (GEN) is positively correlated with } \\
\text { individuals' Prosocial Attitude (PSA). }\end{array}$ & Supported \\
\hline H4: There are differences between males and females regarding \\
concern for the future (GEN)
\end{tabular}




\begin{tabular}{|l|c|}
\hline $\begin{array}{l}\text { H6: There are differences between people with children and people } \\
\text { without children regarding concern for the future (GEN) }\end{array}$ & Supported \\
\hline $\begin{array}{l}\text { H7: There are differences between PT and UK individuals regarding } \\
\text { concern for the future (GEN) }\end{array}$ & Not supported \\
\hline
\end{tabular}

As the data suggests concern for the future is an influential factor in individuals' green consumption values and buying behaviour. This lends further support to the work of others (Urien and Kilbourne 2011; Matsuba et al. 2012; Wells et al., 2016).

While research notes inconsistency between prosocial affect and corresponding behaviours (Osgood and Muravens 2015), it is suggested that the social context (and concern for others) can be an indicator of green behavior (Welte and Anastasio 2010) and that consumers are driven by both emotional and social considerations (Sangroya and Nayak 2017). The results in this study provide new evidence of a positive relationship between concern for the future and prosocial attitude. Other studies suggest the role of social value in green product consumer behavior (Khan and Mohsin 2017) and in relation to other factors but not in relationship to generativity.

The results on gender suggest that in relation to concern for the future there are no differences - an outcome that neither supports nor refutes other studies, given that previous research has not specifically regarded gender in relation to generativity.

The positive results in relation to age and the presence of children can both be considered in relation to the founding work on the concept of generativity which suggested it altered across life stages (Ericson 1950) and Warburton and Gooch (2007) who reported higher levels of generativity in older adults. The results also lend support to the research of McAdams and Aubin 1992 where higher levels of generativity were reported in the population that had children. Research on green consumption supports that age is a variable that impacts green 
consumption (Sun et al 2019) generally, but such studies did not set out to consider age in relation to generativity but rather directly in relation to green behavior.

Finally, as reported in other studies (see above) this study confirms no difference on the basis of country of origin of the respondents.

\section{Conclusion}

Environmental degradation, climate inconsistencies and natural resource depletion have contributed to centralising the need for sustainable development, with a growing awareness of the importance of conserving the planet for future generations. In parallel, environmentally friendly consumption has not only increased but has become an important focus both for research and for producers of more sustainable goods and services. Many studies have focused on developing models to understand the relationship between various concepts that influence purchasing decisions, albeit that, studies have not been able to ascertain why there is a gap between intention and the actual action of buying greener products. This paper has not sought to explore further reasons for that gap, or to propose an alternative model. Instead, it has chosen to highlight the concept of generativity, with the suggestion that concern for the future merits greater consideration given that it is an integral part of the founding definition of sustainable development. .The concept has been explored and tested in this paper, with the suggestion that while other studies have explored a multiplicity of variables that motivate environmentally friendly consumption, concern for the future and the well-being of others, has received limited attention.

A number of hypotheses were formulated to explore the concept further. The results confirm that generativity is positively correlated with individuals' green consumption values, buying behaviour and prosocial attitude. The relationship between generativity and prosocial 
attitude is novel and has not been shown in previous research albeit that some studies have focused on the influence of the social context as a moderating variable. The results do not however, support differences in generativity based on gender, nor do they support differences between the UK and Portugal, which were the two countries that contributed to the data set. Finally, the results also demonstrate a significant relationship between having children and generativity scores, in line with very limited previous research, and a positive relationship between age and generativity, suggesting that older people are more likely to be concerned about future generations. This relationship does perhaps seem intuitively less surprising, given that parenthood with the caring responsibilities involved, might be assumed likely to increase concern for others, and to give rise to the development of emotions and a more altruistic, prosocial frame, that may not be experienced otherwise. Joshi and Rahman (2015) suggest the influence of further concepts, particularly specific emotions merits further study, as it is likely that emotions may drive consumers towards more sustainable buying behaviour and actions. This paper thus, meets a gap in the research and contributes to theory by offering further insights into factors that influence green buying behaviours particularly the influence of generativity and pro-social values. These two concepts merit further analysis; the suggestion that further research is required into emotions is supported.

\subsection{Contribution to theory and practice}

This paper is innovative and contributes to theory by expanding on a concept that has surprisingly received limited attention in the literature. Concern for the future is at the heart of definitions of sustainable development but is insufficiently considered as a research concept. The concept of generativity has been explored in a novel way in relation to green behaviour. Further contribution to theory is made by extending support to existing theory with regard to some hypothesis, by refuting others and in providing new findings. The research relates to practice to the extent that it is important for producers and professionals to understand consumers when seeking to market green products and services. The results highlight that some consumers (those with greater concern for the future) constitute a segment that will be 
more likely to purchase green than others, allowing marketing communications to be appropriately focused; others will need more persuasive strategies. Campaigners seeking to influence behaviour change may wish to consider the emotive aspects of concern for the future, and influence of prosocial attitudes, particularly in those segments where the presence of children is likely to be influential and older generations may be more easily targeted. Further, if a sustainable future is to be secured it will be important to understand not just how to appeal to those who already care, but to develop approaches to get those who care less, to act more altruistically towards generations to follow, with behaviour less focused on their own immediate needs.

The study does however have a number of limitations: firstly, data has been used from a larger data set. The data was obtained through an online questionnaire where the approach to sampling was not purposive. The data also only involves two countries and a wider data set might yield different results. Further the study was intended as exploratory in nature so analysis has been limited to testing relationships. Future studies might seek to test the concept further, ascertain how it might fit within existing models of green consumption and extend to other countries. Measures to tap other concepts such as altruism, might also be useful additions to the items used to test concern for the future and the emotional aspects of concern for others.

The authors conclude that concern for the future and the concept of generativity will be important in relation to behaviour change; further investigation will be valuable.

\section{References}

Alisat, S. (2015). Living the green life: a mixed-methods examination of the relationship between generativity and environmental engagement in emerging and mid-life Canadian activists and nonactivists. Theses and Dissertations (Comprehensive). 1709. http://scholars.wlu.ca/etd/1709. 
Bailey, A., Mishra, A., Tiamiyu M. (2016a). GREEN consumption values and Indian consumers' response to marketing communications. Journal of Consumer Marketing, 3(7), 562-573.

Bailey, A., Mishra, A., Tiamiyu, M. (2016b). Green advertising receptivity: An initial scale development process. Journal of Marketing Communications. 22(3), 327-345.

Biswas, A. (2017). A consumption value-gap analysis for sustainable consumption. Environmental Science and Pollution Research, 24, 7714-7725.

Carfora, V., Caso, D., Sparks, P., Conner, M. (2017). Moderating effects of proenvironmental self-identity on pro-environmental intentions and behaviour: A multi-behaviour study. Journal of Environmental Psychology, 53, 92-99.

Carson, R. (1962). Silent Spring. Houghton Mifflin.

Chan, T. S. (2009). Environmental sustainability as a generative Concern: An exploratory study of the narrative identities of leaders in the environmental sustainability movement. Evanston: Northwestern University (Doctoral Thesis).

Chen, T.B., Chai, L.T. (2010). Attitude towards the environment and green products: Consumers' perspective. Management Science and Engineering, 4 (2), 27-39.

Erikson, E. (1950). Childhood and society. New York: Norton.

European Commission (2014). Special Eurobarometer 416 Attitudes of European citizens towards the environment.

http://ec.europa.eu/commfrontoffice/publicopinion/archives/ebs/ebs_416_en.pdf. Accessed at $14 / 07 / 17$. 
Frensch, K., Pratt, M., Norris, J. (2007). Foundations of generativity: personal and family correlates of emerging adults' generative life-story themes. Journal of Research in Personality, 41(1), 45-62.

Grunert, S. C., Juhl, H. J. (1995). Values, environmental attitudes, and buying of organic foods. Journal of Economic Psychology, 16(1), 39-62.

Haws, K.L., Winterich, K.P., Naylor, R.W. (2014). Seeing the world through GREEN-tinted glasses: green consumption values and responses to environmentally friendly products. Journal of Consumer Psychology, 24(3), 336-354.

He, A., Cai, T., Deng, T., Li, X. (2016). Factors affecting non-green consumer behaviour: an exploratory study among Chinese consumers. International Journal of Consumer Studies, 40, 345-356.

HAN, H.; HSU, L.-T. (Jane); LEE, J.-S. (2009) Empirical investigation of the roles of attitudes toward green behaviors, overall image, gender, and age in hotel customers' eco-friendly decision-making process. International Journal of Hospitality Management, [s. I.], v. 28, n. 4, p. 519-528.

Khan, S. N., \& Mohsin, M. (2017). The power of emotional value: Exploring the effects of values on green product consumer choice behavior. Journal of Cleaner Production, 150, 6574.

Joshi, Y., Rahman, Z. (2015). Factors Affecting Green Purchase Behaviour and Future Research Directions. International Strategic Management Review, 3(1), 128-143.

Kotre, J. (1984). Outliving the self. Baltimore, MD: Johns Hopkins University Press.

Leal Filho, W (2000). Dealing with misconceptions on the concept of sustainability. International Journal of Sustainability in Higher Education, 1(1), 9-19, https://doi.org/10.1108/1467630010307066 
LEE, K. Gender differences in Hong Kong adolescent consumers' green purchasing behavior. (2009). Journal of Consumer Marketing, [s. I.], v. 26, n. 2, p. 87-96.

Liobikiene, G., Bernatoniene, J. (2017). Why determinants of green purchase cannot be treated equally? The case of green cosmetics: literature review. Journal of Cleaner Production. 162, 109-120.

Malik, M.U. (2017). 'Demographic Trends in Green Purchase Behavior; A Study of Pakistani Youth Segment', International Interdisciplinary Journal of Scholarly Research (IIJSR), (1), p. 36.

Matsuba, M. K., Pratt, M. W., Norris, J. E., Mohle, E., Alisat, S., McAdams, D. P. (2012). Environmentalism as a context for expressing identity and generativity: patterns among activists and uninvolved youth and midlife adults. Journal of Personality, 80(4).

McAdams, D. P., Logan, R. L. (2004). What is generativity? In E. de St. Aubin, D. P. McAdams, \& T.-C. Kim (Eds.). The generative society: Caring for future generations (pp. 1531). Washington, DC, US: American Psychological Association. http://dx.doi.org/10.1037/10622-002

McAdams, D., de St. Aubin, E. (1992). A theory of generativity and its assessment through self-report, behavioural acts, and narrative themes in autobiography. Journal of Personality and Social Psychology. 62(6), 1003-1015.

Meadows, D.H., Randers, J., Meadows, D.L. (1977). Limits to Growth: A Report for the Club of Rome's Project on the Predicament of Mankind, New American Library.

Mostafa, M. M. (2007). Gender differences in Egyptian consumers' green purchase behaviour: the effects of environmental knowledge, concern and attitude. International Journal of Consumer Studies, 31(3), 220-229. 
Nath, V., Kumar, R., Agrawal, R., Gautam, A., Sharma, V. (2013). Consumer adoption of green products: modeling the enablers. Global Business Review, 14(3), 453-470.

Osgood, J.M., Muraven, M. (2015). Self-control depletion does not diminish attitudes about being prosocial but does diminish prosocial behaviors. Basic and Applied Social Psychology. $37,68-80$.

Paço, A., Alves, H., Shiel, C., Leal Filho, W. (2013a). Development of a green consumer behavior model. International Journal of Consumer Studies. 37, 414-429.

Paço, A., Alves, H., Shiel, C., Leal Filho, W. (2013b). A multi-country level analysis of the environmental attitudes and behaviours among young consumers, Journal of Environmental Planning and Management, DOI:10.1080/09640568.2012.733310.

Paço, A., Alves, H., Shiel, C., Leal Filho, W. (2014). An analysis of the measurement of the construct "buying behaviour" in green marketing. Journal of Integrative and Environmental Sciences, 11(1), 55-69.

Paço, A., Shiel, C., Alves, H. (2019). A new model for testing green consumer behavior Journal of Cleaner Production, 207, 998-1006, https://doi.org/10.1016/j.jclepro.2018.10.105.

Paço, A., Reis, R. (2012). Factors Affecting Skepticism toward Green Advertising. Journal of Advertising, 41(4), 147-155, DOI: 10.1080/00913367.2012.10672463

Ryff C, Heincke S. (1983). Subjective organization of personality in adulthood and aging. Journal of Personality and Social Psychology, 44, 807-816.Sangroya D, Nayak JK. (2017). Factors influencing buying behaviour of green energy consumer. Journal of Cleaner Production. 2017;151:393-405.

Steele, W.R., Schreiber, G.B., Guiltinan, A., Nass, A., Glynn, S., Wright, D., Kessler, D., Schlumpf, K., Tu, Y., Smith, J.W., Garratty, G. (2008). The role of altruistic behavior, 
empathetic concern, and social responsibility motivation in blood donation behavior. Transfusion, 48, 43-54.

Straughan, R., Roberts, J. (1999). Environmental segmentation alternatives: a look at green consumer behaviour in the new millennium. Journal of Consumer Marketing 16(6), 558-575.

Sun Y, Liu N, Zhao M. (2019). Factors and mechanisms affecting green consumption in China: A multilevel analysis. Journal of Cleaner Production. 2019;209:481-493.

Tripathi, A., Singh, M. (2016). Determinants of sustainable/green consumption: a review, International Journal of Environmental Technology and Management, 19(3/4), 316- 358.

United Nations (1945). United Nations Charter, 26 June 1945, 59 Stat. 1031, T.S.993.

United Nations (1972). Report of the United Nations Conference on the Human Environment. Stockholm, 5-16 June. http://www.un-documents.net/aconf48-14r1.pdf Accessed 10 Oct 2018 .

United Nations (2015). Transforming our World: The 2030 Agenda for Sustainable Development.

https://sustainabledevelopment.un.org/post2015/transformingourworld/publication. Accessed 12 Oct 2018.

Urien, B., Kilbourne, W. (2011). Generativity and self-enhancement values in eco-friendly behavioural intentions and environmentally responsible consumption behaviour, Psychology \& Marketing, 28(1), 69-90.

Warburton, J. \& Gooch, Margaret. (2007). Stewardship Volunteering by Older Australians: The Generative Response. Local Environment. 12. 10.1080/13549830601098230.

WCED (1987). Our Common Future, World Commission on Environment and Development, Oxford: Oxford University Press. 
Weinstein, N., Ryan, R.M., 20132010. When helping helps: autonomous motivation for prosocial behavior and its influence on well-being for the helper and recipient. J Pers Soc Psychol. 98(2), 222-244.

Weiss, B. (1992). Intergenerational equity: a legal framework for global environmental change. In Environmental change and international law: New challenges and dimensions. Edited by Edith Brown Weiss. Tokyo: United Nations University Press

Wells, V., Taheri, B., Gregory-Smith, D., Manika, D. (2016). The role of generativity and attitudes on employees home and workplace water and energy saving behaviours. Tourism Management, 56, 63-74.

Welte, T., Anastasio, P. (2010). To conserve or not to conserve: is status the question? Environment and Behavior, 42, 845.

Whitmarsh, L., O'Neill, S. (2010). Green identity, green living? The role of pro-environmental self-identity in determining consistency across diverse pro-environmental behaviours. Journal of Environmental Psychology, 30(3), 305-314.

World Commission on Environment and Development [WCED] (1987), Our Common Future, Oxford University Press, Oxford.

Zabkar, V., Hosta, M. (2013). Willingness to act and environmentally conscious consumer behaviour: can prosocial status perceptions help overcome the gap? International Journal of Consumer Studies. 37, 257-264. 


\section{Appendix A}

\section{General Prosocial Attitudes (GPA)}

GPA1 It is important that others are happy

GPA2 It is important to help someone who needs it

GPA3 I want to help others

GPA4 The well-being of others is important

GPA5 The needs of others are important

GPA6 It is important that all people are happy

\section{Generativity(GEN)}

GEN1 I try to pass along the knowledge I have gained through my experiences.

GEN2 I do not feel that other people need me.

GEN3 I feel as though I have made a difference to many people.

GEN4 I have made and created things that have had an impact on other people.

GEN5 I try to be creative in most things that I do.

GEN6 I think that I will be remembered for a long time after I die.

GEN7 Others would say that I have made unique contributions to society.

GEN8 I have important skills that I try to teach others.

GEN9 I feel that I have done nothing that will survive after I die.

GEN10 In general, my actions do not have a positive effect on other people.

GEN11 I feel as though I have done nothing of worth to contribute to others.

GEN12 I have made many commitments to many different kinds of people, groups, and activities in my life.

GEN13 Other people say that I am a very productive person.

GEN14 I have a responsibility to improve the neighborhood in which I live.

GEN15 People come to me for advice.

GEN16 I feel as though my contributions will exist after I die.

\begin{tabular}{ll}
\hline & \multicolumn{1}{c}{ Green Consumption Values (GREEN) } \\
\hline GRE1 & It is important to me that the products I use do not harm the environment \\
GRE2 & I consider the potential environmental impact of my actions when making many of my decisions \\
GRE3 & My purchase habits are affected by my concern for our environment \\
GRE4 & I am concerned about wasting the resources of our planet \\
GRE5 & I would describe myself as environmentally responsible \\
GRE6 & I am willing to be inconvenienced in order to take actions that are more environmentally friendly \\
\hline & \\
\hline BB1 & I try to buy energy efficient products and appliances \\
BB2 & I avoid buying products that have excessive packaging \\
BB3 & When there is a choice, I choose the product that causes the least pollution \\
BB4 & I have switched products/brands for ecological reasons \\
BB5 & I make every effort to buy paper products made from recycled paper \\
BB6 & I use environmentally friendly soaps and detergents \\
BB7 & I have convinced members of my family or friends not to buy some products which are harmful to \\
the environment & Whenever possible, I buy products packaged in reusable containers \\
BB8 & I try to buy products that can be recycled \\
BB9 & I buy high efficiency light bulbs to save energy \\
BB10 & \\
\hline
\end{tabular}

